\title{
Tetrahedron
}

\section{$N$-phenanthroline glycosylamines: synthesis and copper(II) complexes}

\author{
Katerina Duskova, Lourdes Gude and María-Selma Arias-Pérez * \\ Departamento de Química Orgánica y Química Inorgánica, Universidad de Alcalá, 28871 Alcalá de Henares, Madrid, Spain
}

\section{ABSTRACT}

A series of novel $N$-(1,10-phenanthrolin-5-yl)- $\beta$-glycopyranosylamines was obtained with excellent stereoselectivity and synthetically useful yields by treatment of 5 -amino-1,10phenanthroline with different unprotected monosaccharides, using $\left(\mathrm{NH}_{4}\right)_{2} \mathrm{SO}_{4}$ as an efficient promoter. Copper(II) complexes having a 2:1 mole ratio of the bidentate ligand phenanthroline $\mathrm{N}$-glycoside and the metal were also prepared.

2013 Elsevier Ltd. All rights reserved.

Glycosylamines

$\mathrm{N}$-glycosylation reactions

Phenanthroline derivatives

Copper(II) complexes

\section{Introduction}

Glycosylamines are important in carbohydrate enzymology and some of them are considered to be inhibitors of glycosidases. ${ }^{1}$ Inhibition of glycosidase enzymes is at the heart of the therapy of numerous diseases, since they are involved in varied and essential biological processes. Thus, rebeccamycin analogues are indolocarbazole $N$-glycosides with antitumor activity that can inhibit topoisomerase I, kinases and/or bind to DNA according to their chemical structure. ${ }^{2}$ Many carbohydrates, both neutral and positively charged, are known to be generally good binders for nucleic acids, and the interaction occurs mainly throughout the minor groove because of their hydrogen-bonding ability and large hydrophobic patches. On the other hand, heterocyclic compounds such as 1,10-phenanthroline and 2,2'bipyridine are powerful bidentate metal chelators with applications in diverse areas, and different metal complexes have been extensively studied for their nuclease-like activity.,

The development of novel chemical compounds capable of modulating human telomerase activity is currently a very active and competitive area of research, mainly because of its potential applications in the treatment of cancer and age-related diseases. ${ }^{5,6}$ The enzymatic activity of this ribonucleoprotein, encharged of telomere length maintenance in humans, is overexpressed in 85$90 \%$ of cancer patients, ${ }^{7}$ which has led to the recognition of telomerase as a feasible drug target. ${ }^{8}$ Among the different approaches for the design of telomerase inhibitors, selective Gquadruplex ligands are currently attracting much attention, ${ }^{9}$ due to the prevalence of DNA G-quadruplex folding architectures in many genomic regions of biological interest, such as gene promoters and human telomeres. ${ }^{9,10}$

We are interested in the preparation of metallo-organic molecules that can selectively bind and stabilize the Gquadruplex DNA structures, ${ }^{11}$ as they can act as human telomerase inhibitors. ${ }^{12,13}$ Some common structural features of the designed compounds have been shown to contribute to binding: they are water-soluble metal complexes containing flat aromatic surfaces - to favour $\pi$ stacking interactions with the DNA Gtetrads-, ${ }^{11}$ they incorporate lateral side-chains that can act as groove binding moieties by electrostatic interactions and/or $\mathrm{H}$ bonds, and they contain positively charged metal atoms to simulate the role of potassium or sodium ions at stabilizing the quadruplex structure under physiological conditions. ${ }^{12}$ Phenanthroline serves as the scaffold for several potent stabilizers of DNA G-quadruplexes, ${ }^{13}$ which can act as human telomerase inhibitors and are currently receiving much attention as potential targets for anticancer drug development.

Based on the hypothesis that sugars add important features to the shape and the stereoelectronic properties of a molecule and often play an essential role in the biological activity, we wished to explore the DNA-binding properties of metal complexes of $\mathrm{N}$ heteroaryl glycosylamines including two structural components: a heteroaromatic system -DNA intercalating moiety- and a carbohydrate unit- minor/major groove-binding moiety- (Scheme 1). Although few data have been reported about the interactions 


\section{minor/major groove planar heteroaromatic system
as DNA intercalating moiety binding moiety}

1<smiles>Nc1cc2cccnc2c2ncccc12</smiles>

\section{$\underset{\left(\mathrm{NH}_{4}\right)_{2} \mathrm{SO}_{4} \text { (cat.) }}{\mathrm{MeOH}}$ $65^{\circ} \mathrm{C}, 24 \mathrm{~h}$}
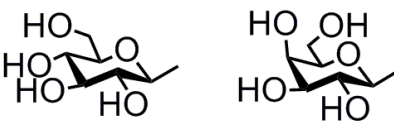

b

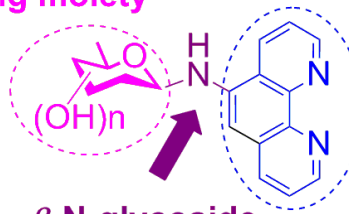

$\beta$-N-glycoside linker

2a-e

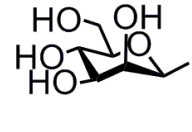

C

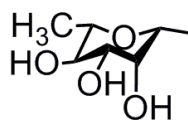

d

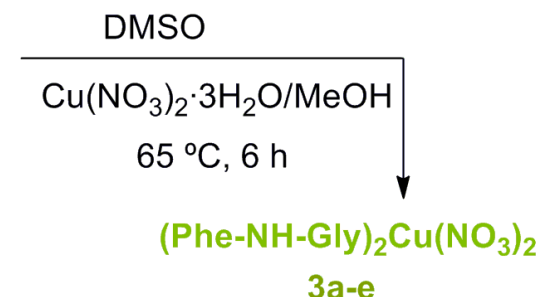

3a-e

Scheme 1

Table 1. $\mathrm{N}$-Glycosylation reactions of 5-amino-1,10-phenanthroline

\begin{tabular}{|c|c|c|c|c|c|c|}
\hline Entry & Monosaccharide & Method $^{\mathrm{a}}$ & Reaction medium & $\begin{array}{c}\text { Temperature } \\
\left({ }^{\circ} \mathrm{C}\right)\end{array}$ & $\begin{array}{c}\text { Reaction } \\
\text { time }(\mathrm{h})\end{array}$ & $\begin{array}{c}\text { Glycopyranosylamine, } \\
\text { yield }(\%)^{\mathrm{c}}\end{array}$ \\
\hline 1 & D-glucose & A & Methanol & 65 & 72 & $\mathbf{2 a}, 20-26$ \\
\hline 2 & & $\mathrm{~B}$ & $\begin{array}{l}\text { Aqueous phosphate } \\
\text { buffer }^{\text {b }}\end{array}$ & 40 & 5 & 12 \\
\hline 3 & & $\mathrm{C}$ & $\begin{array}{c}\text { Methanol-aqueous } \\
\text { phosphate buffer }(1: 1)\end{array}$ & 65 & 74 & 72 \\
\hline 4 & & $\mathrm{D}$ & Methanol/( $\left(\mathrm{NH}_{4}\right)_{2} \mathrm{SO}_{4}$ & 65 & 24 & 88 \\
\hline 5 & & & & 65 & 48 & 79 \\
\hline 6 & D-galactose & $\mathrm{D}$ & Methanol/( $\left(\mathrm{NH}_{4}\right)_{2} \mathrm{SO}_{4}$ & 65 & 24 & $\mathbf{2 b}, 68$ \\
\hline 7 & D-mannose & $\mathrm{D}$ & Methanol/ $\left(\mathrm{NH}_{4}\right)_{2} \mathrm{SO}_{4}$ & 65 & 24 & $2 c, 90$ \\
\hline 8 & & & & 65 & 48 & 80 \\
\hline 9 & L-rhamnose & $\mathrm{D}$ & Methanol/( $\left(\mathrm{NH}_{4}\right)_{2} \mathrm{SO}_{4}$ & 65 & 24 & $\mathbf{2 d}, 90$ \\
\hline 10 & & & & 65 & 48 & 81 \\
\hline 11 & L-fucose & $\mathrm{D}$ & Methanol/ $\left(\mathrm{NH}_{4}\right)_{2} \mathrm{SO}_{4}$ & 65 & 24 & $2 e, 67$ \\
\hline
\end{tabular}

between carbohydrates and G-quadruplexes, recent studies on sugar-DNA conjugates have shown that favourable interactions occur between the carbohydrate and the DNA G-tetrad through stacking interactions as well as hydrogen bonding or hydrophobic contacts, when they are available. ${ }^{14}$ Moreover, it has been shown that carbohydrates can give rise to significant differences in the affinity for a quadruplex target and they are promising motifs for selective G-quadruplex recognition and the design of new Gquadruplexes ligands. ${ }^{14,15}$

In this paper we describe the synthesis and characterization of a series of $N$-(1,10-phenanthrolin-5-yl)- $\beta$-glycopyranosylamines 2a-e and their copper(II) complexes (Scheme 1). $N$-glycosylation reactions were accomplished by treatment of 5-amino-1,10phenanthroline with different unprotected monosaccharides using $\left(\mathrm{NH}_{4}\right)_{2} \mathrm{SO}_{4}$ as a convenient promoter. To the best of our knowledge, these phenanthroline $N$-glycosides and their complexes have been not reported previously.

\section{Results and discussion}

Few synthetic methods have been reported for the direct $N$ glycosylation of aromatic compounds and carbohydrates without hydroxyl protection or activation. ${ }^{16-23}$ Usually, the reaction can be accomplished by heating at reflux in protic solvents and, in some cases, better results can be achieved under mildly acidic conditions. ${ }^{16-23}$ It is known that the reaction is strongly influenced by the reactivity of the starting amine and the best preparative yields were obtained for aromatic amines of moderate basicity. ${ }^{18-}$ ${ }^{20}$ An increase of the amine basicity seems to be related with lesser stability of the $\mathrm{N}$-glycoside, which undergoes side reactions more easily. ${ }^{18}$ Hydrolysis, Amadori rearrangement or melanoidine formation were described mainly in water, at high temperature and in acid media. ${ }^{18,21,22}$ Moreover, the steric features of the amine and the sugar as well as the reaction conditions exert a strong influence on the stereoselectivity of the $N$-glycosylation. Frequently, mixtures of the $\alpha$ and $\beta$ anomers are obtained. ${ }^{1923}$ 
As a first step toward the synthesis of the $N$-phenanthroline glycosylamines, we decided to study the $\mathrm{N}$-glycosylation of 5amino-1,10-phenanthroline and D-glucose in order to optimize 1 the reaction conditions in terms of yield, reaction time and
Table 2. Selected NMR parameters of the $N$ - $\beta$-glycopyranosylamines $\mathbf{2 a - e}$

\begin{tabular}{ccccccc}
\hline & $\mathbf{1}$ & $\mathbf{2 a}$ & $\mathbf{2 b}$ & $\mathbf{2 c}$ & $\mathbf{2 d}$ & $\mathbf{2 e}$ \\
\hline$\delta(\mathrm{ppm})$ & & & & & & \\
$\mathrm{H}-1$ & - & 4.64 & 4.62 & 5.01 & 5.02 & 4.62 \\
$\mathrm{NH}$ & 6.14 & 6.89 & 6.90 & 6.27 & 6.24 & 6.86 \\
$\mathrm{H}-6$, & 6.84 & 7.00 & 7.01 & 7.07 & 7.03 & 6.97 \\
$\mathrm{H}-7$ & 8.03 & 8.12 & 8.11 & 8.13 & 8.20 & 8.17 \\
$\mathrm{H}-4$, & 8.66 & 8.84 & 8.87 & 8.60 & 8.59 & 8.86 \\
$\mathrm{C}-1$ & - & 84.7 & 85.2 & 81.4 & 81.0 & 84.8 \\
${ }^{J}(\mathrm{~Hz})$ & & & & & & \\
${ }^{3} J_{\mathrm{H} 1-\mathrm{H} 2}$ & - & 8.4 & 8.5 & - & - & 8.5 \\
${ }^{3} J_{\mathrm{H} 1-\mathrm{NH}}$ & - & 7.7 & 7.6 & 9.0 & 9.0 & 7.9 \\
${ }^{1} J_{\mathrm{C} 1-\mathrm{H} 1}$ & - & 151 & 151 & 158 & 157 & 151 \\
\hline
\end{tabular}

ppm and the introduction of carbohydrate moieties only slightly affected their chemical shifts. From COSY and TOCSY correla tions two groups of aromatic signals could be differentiated. The assignment of these sets of signals to the two pyridine rings of the phenanthroline system was based on the NOE correlations found in the 2D ROESY spectra (Scheme 2). Thus, in the case of 2a the correlation between the singlet due to $\mathrm{H}_{-6}{ }^{\prime}$ at $7.00 \mathrm{ppm}$ and the doublet of doublets centred at $8.12 \mathrm{ppm}$ allowed the assignment of this signal to $\mathrm{H}-7$ ' while $\mathrm{H}-4$ ' resonates at 8.84 ppm. The analysis of the direct and long-range ${ }^{1} \mathrm{H}-{ }^{13} \mathrm{C}$ correlated spectra (gC2HSQCSE and $\mathrm{gCH} 2 \mathrm{MBC}$ ) allowed the assignment of carbon resonances, once the signals of the respective protons were established. Data are given in Table 2 and in the experimental section.

The $\beta$-anomeric configuration was assigned on the basis of NOE experiments (2D ROESY spectra). The NOE cross-peaks observed between $\mathrm{H}-1$ and $\mathrm{H}-3 / \mathrm{H}-5$ protons in all cases and between $\mathrm{H}-1$ and $\mathrm{H}-2$ protons in $\mathbf{2 c}, \mathbf{d}$ (Scheme 2) indicate an axial disposition of the anomeric proton. In $\mathbf{2 a}, \mathbf{b}, \mathbf{e}$ the large vicinal coupling constant of 7.6-7.9 Hz between anomeric $\mathrm{H}-1$ and $\mathrm{H}-2$ shows their trans-diaxial orientation and corroborates $\beta$ configuration. ${ }^{17,19,23,24}$ Moreover, anomeric proton and carbon chemical shifts ${ }^{17,19,23,24}$ as well as the value of the ${ }^{13} \mathrm{C}-{ }^{1} \mathrm{H}$ direct coupling constant for the C-1 carbon $\left({ }^{1} \mathrm{~J}_{\mathrm{CH}}=151-158 \mathrm{~Hz}\right.$, Table $2)^{25}$ also support this statement. The experimental values of the vicinal coupling constants for the protons of the pyranoside ring indicate that these derivatives are almost completely in the ${ }^{4} \mathrm{C}_{1}$ conformation $(\mathbf{2 a}, \mathbf{b}, \mathbf{c})$ or ${ }^{1} \mathrm{C}_{4}$ form $(\mathbf{2 d}, \mathbf{e})$. The large values of coupling constants ${ }^{3} \mathbf{J}_{\mathrm{NH}-\mathrm{H} 1}(7.6-9.0 \mathrm{~Hz}$, Table 2) are consistent with an anti relationship between $\mathrm{NH}$ and $\mathrm{H}-1$ in $\left(\mathrm{CD}_{3}\right)_{2} \mathrm{SO}$ solution and may be rationalized in terms of a conformation around $\mathrm{C} 1-\mathrm{N}$ bond that exhibits stabilizing exo-anomeric interactions, ${ }^{25}$ greater for $\beta$-manno and $\beta$-rhamno derivatives

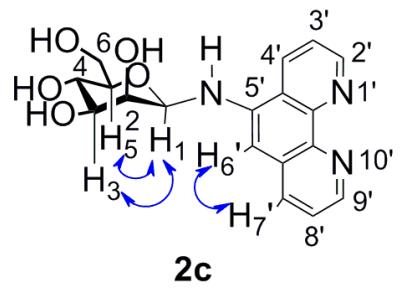

Scheme 2 
$(\mathbf{2 c}, \mathbf{d})$. The comparison of the aromatic and $\mathrm{NH}$ proton chemical shifts of the $\mathrm{N}$-glycopyranosilamines 2a-e with those of the

parent amine 1 indicates a deshielding of $\mathrm{NH}$ (ca. $0.7 \mathrm{ppm}$ ) and aromatic H-4' and H-6' protons (ca. $0.2 \mathrm{ppm}$ ) when 2-OH adopts an equatorial position (2a,b,e, Table 2). The different values of ${ }^{3} \mathbf{J}_{\mathrm{NH}-\mathrm{H} 1}$ seem to be also influenced by the spatial disposition of the 2-OH. These findings might be related to a small dependence of these parameters on the conformation around the $\mathrm{C} 1-\mathrm{N}$ bond and/or the hydrogen bonding pattern, influenced by the $2-\mathrm{OH}$ spatial orientation.

The $\mathrm{Cu}(\mathrm{II})$ complexes 3a-e were characterized by elemental analysis, MS spectrometry and FTIR-spectroscopy. A common structural feature in these derivatives is the presence of a 2:1 mole ratio of the bidentate ligand and the metal. In order to avoid interferences, ESI-MS spectra were recorded using water as mobile phase. When the spectra were obtained in aqueous acetic acid higher fragmentation and partial interchange of $\mathrm{NO}_{3}{ }^{-}$anion for $\mathrm{CH}_{3} \mathrm{COO}^{-}$was observed leading to a superposition of sets of peaks with $\mathrm{m} / \mathrm{z}$ differences of 3 units. Thus, for $\mathbf{3 a}[\mathrm{Cu}(\mathrm{Phe}-\mathrm{NH}-$ Gly $\left.)_{2} \mathrm{NO}_{3}\right]^{+} / \quad\left[\mathrm{Cu}(\mathrm{Phe}-\mathrm{NH}-\mathrm{Gly})_{2} \mathrm{CH}_{3} \mathrm{COO}\right]^{+}$and $[\mathrm{Cu}(\mathrm{Phe}-\mathrm{NH}-$ Gly) $\left.\mathrm{NO}_{3}\right]^{+} /\left[\mathrm{Cu}(\mathrm{Phe}-\mathrm{NH}-\mathrm{Gly}) \mathrm{CH}_{3} \mathrm{COO}^{+}\right.$species were found in the spectrum. In these conditions the divalent fragment $[\mathrm{Cu}(\mathrm{Phe}-$ $\left.\mathrm{NH}-\mathrm{Gly})_{2}\right]^{2+}$ was also detected. In general, the complexes exhibited very comparable IR features, suggesting that they are of similar structure. A sharp band at ca. $1384 \mathrm{~cm}^{-1}$ appeared after complex formation which was assigned to $\mathrm{NO}_{3}^{-}$vibration. The strong broad band in the region of $3300-3400 \mathrm{~cm}^{-1}$ corresponding to $\mathrm{O}-\mathrm{H}$ and $\mathrm{N}-\mathrm{H}$ stretching vibrations showed a shift of $40 \mathrm{~cm}^{-1}$ towards lower frequency in $\mathbf{3 b}$ while it was shifted to higher frequency in $\mathbf{3 c}\left(50 \mathrm{~cm}^{-1}\right), \mathbf{3 d}\left(72 \mathrm{~cm}^{-1}\right)$ and $\mathbf{3 e}\left(20 \mathrm{~cm}^{-1}\right)$ compared to the ligands. These changes might be related to the existence of different hydrogen bond networks in complexes and in the free $\mathrm{N}$-glycopyranosylamines.

The same coordination environments around copper centre can be assumed for the $\mathrm{Cu}(\mathrm{II})$ complexes 3a-e bearing in mind the similar behaviour observed. However, detailed structure studies by X-ray analysis were not possible because of the difficulties in obtaining suitable crystals, and exact coordination geometry and spatial disposition of the non-symmetrical substituted $\mathrm{N}$-phenanthroline glycosylamine ligands could not be established. Structure studies on related $\mathrm{Cu}(\mathrm{II})$ complexes indicate that the copper atom is usually pentacoordinate and that geometries ranging from distorted trigonal bipyramidal to square pyramidal are typical of them. ${ }^{26}$

\section{Conclusion}

Treatment of 5-amino-1,10-phenanthroline with different unprotected monosaccharides under optimized conditions led to $N$-(1,10-phenanthrolin-5-yl)- $\beta$-glycopyranosylamines with excellent stereoselectivity and synthetically useful yields. $\mathrm{Cu}(\mathrm{II})$ complexes having a 2:1 mole ratio of the bidentate ligand phenanthroline $\mathrm{N}$-glycoside and the metal were also prepared with good yields. Regarding the potential applications, the high solubility of these metallo-organic compounds may be particularly important for an efficient activity. In addition, the introduction of chirality via the carbohydrate unit might confer selectivity and good binding affinity towards the chiral DNA biomolecule. Further experiments designed to confirm these hypotheses are currently underway.

\section{Experimental}

\subsection{General methods}

All reagents were commercially available (Sigma-Aldrich) in high purity and used as received. The $N$-glycosylation reactions were monitored by thin-layer chromatography (TLC) and their composition was determined by ${ }^{1} \mathrm{H}-\mathrm{NMR}$ spectroscopy. TLC was performed on precoated Kieselgel $60 \mathrm{~F}_{254}$ aluminium sheets; plates were eluted with methanol, dried and then eluted with methanol- $\mathrm{NH}_{4} \mathrm{OH}$ (30\%) 10:1; detection was first by UV and then by charring with sulphuric acid in ethanol $(1: 4, v / v)$. Flash chromatography was performed on Fluka Silica Gel 60 (230-400 mesh) enriched with approx. $0.1 \% \mathrm{Ca}$, using methanol as eluent. Melting points were taken on an Electrothermal Digital IA9100 apparatus and were uncorrected. Optical rotations were measured in HPLC grade dimethylsulfoxide on a Perkin-Elmer 341 polarimeter; $[\alpha]_{\mathrm{D}}$ values are given in $10^{-1} \mathrm{deg} \cdot \mathrm{cm}^{2} \cdot \mathrm{g}^{-1}$; concentration is given in $\mathrm{mg} \cdot \mathrm{mL}^{-1}$. $\mathrm{FAB}$ mass spectra were obtained on a V. G. Autoexpec spectrometer using 3-nitrobenzyl alcohol as the matrix. ESI mass (+ mode) spectra were performed on a Thermo Scientific TSQ Quantum LC/MS or an Agilent 6210 LC/MS/TOF instruments. IR spectra ( $\mathrm{KBr}$ disks) were recorded on a FT-IR Perkin-Elmer Spectrum 2000 spectrophotometer. All NMR spectra $\left({ }^{1} \mathrm{H},{ }^{13} \mathrm{C}, 2 \mathrm{D}{ }^{1} \mathrm{H}-{ }^{1} \mathrm{H}\right.$ gCOSY, TOCSY, ROESYAD, gC2HSQCSE, gCH2MBC) were recorded on a Varian 300 UNITY-Plus or VNMRS-500 spectrometer in $\left(\mathrm{CD}_{3}\right)_{2} \mathrm{SO}$ at $298 \mathrm{~K}$ using standard pulse sequences. Chemical shifts are reported relative to the residual $\left(\mathrm{CHD}_{2}\right)_{2} \mathrm{SO}\left(\delta_{\mathrm{H}} 2.50 \mathrm{ppm}\right)$, or $\left(\mathrm{CD}_{3}\right)_{2} \mathrm{SO}$ $\left(\delta_{\mathrm{C}} 39.5 \mathrm{ppm}\right)$; resonance patterns are reported with the notations $\mathrm{s}$ (singlet), d (doublet), t (triplet), q (quartet), and m (multiplet); in addition, the notations ap and br are used to indicate an apparent multiplicity and a broad signal; geminal H-6 protons at the sugar moieties resonating at low and high frequency were assigned as $\mathrm{H}-6 \mathrm{a}$ and $\mathrm{H}-6 \mathrm{~b}$, respectively. Lorentz-Gauss transformation was used to improve the resolution of the ${ }^{1} \mathrm{H}$ NMR spectra. Errors: ${ }^{1} \mathrm{H}, \delta \pm 0.01 \mathrm{ppm}, J \pm 0.1 \mathrm{~Hz} ;{ }^{13} \mathrm{C}, \delta \pm 0.1$ ppm.

5-Amino-1,10-phenanthroline (1) was prepared from 5-nitro1,10 -phenanthroline as previously described ${ }^{27}$ by reduction with hydrazine hydrate using $\mathrm{Pd} / \mathrm{C} 10 \%$ as catalyst. $\delta_{\mathrm{H}}(500 \mathrm{MHz}$; $\left.\left(\mathrm{CD}_{3}\right)_{2} \mathrm{SO}\right) 6.14\left(2 \mathrm{H}\right.$, br s, $\left.\mathrm{NH}_{2}\right), 6.84(1 \mathrm{H}, \mathrm{s}, \mathrm{H}-6), 7.49(1 \mathrm{H}, \mathrm{dd}$, $J$ 8.1, $4.3 \mathrm{~Hz}, \mathrm{H}-8), 7.72(1 \mathrm{H}, \mathrm{dd}, J 8.4,4.3 \mathrm{~Hz}, \mathrm{H}-3), 8.03(1 \mathrm{H}$, dd, $J 8.1,1.7 \mathrm{~Hz}, \mathrm{H}-7), 8.66(1 \mathrm{H}, \mathrm{dd}, J 8.4,1.7 \mathrm{~Hz}, \mathrm{H}-4), 8.67$ (1H, dd, $J 4.3,1.7 \mathrm{~Hz}, \mathrm{H}-9), 9.04(1 \mathrm{H}, \mathrm{dd}, J 4.3,1.7 \mathrm{~Hz}, \mathrm{H}-2) . \delta_{\mathrm{C}}$ (125 MHz; $\left.\left(\mathrm{CD}_{3}\right)_{2} \mathrm{SO}\right) 101.8$ (C-6), 121.8 (C-4a), 122.0 (C-3), 123.2 (C-8), 130.6 (C-6a), 130.8 (C-4), 132.7 (C-7), 140.5, 142.7 (C-5, C-10a), 144.8 C-9), 146.2 (C-10b), 149.3 (C-2).

\subsection{Synthesis of $N$-(1,10-phenanthrolin-5-yl)- $\beta$-glycopyranosyl amines}

\section{General Procedures}

Method A. 5-Amino-1,10-phenanthroline (49 mg, $0.25 \mathrm{mmol}$ ) was dissolved in $4 \mathrm{~mL}$ of $\mathrm{MeOH}$. D-glucose monohydrate $(0.75$ or $1.00 \mathrm{mmol}$ ) was then added and the mixture was stirred at 65 ${ }^{\circ} \mathrm{C}$. After $72 \mathrm{~h}$, the reaction was allowed to cool to room temperature and concentrated.

Method B. A stirred suspension of 5-amino-1,10-phenanthroline (49 $\mathrm{mg}, 0.25 \mathrm{mmol}$ ) and D-glucose monohydrate $(198 \mathrm{mg}, 1.00$ $\mathrm{mmol}$ ) in $2 \mathrm{~mL}$ of aqueous $\mathrm{Na}_{2} \mathrm{HPO}_{4} / \mathrm{NaH}_{2} \mathrm{PO}_{4},(50 \mathrm{mM}, \mathrm{pH} 6.5)$ was heated at $40^{\circ} \mathrm{C}$ for $5 \mathrm{~h}$. The reaction mixture was worked up as described above.

Method C. This procedure is analogous to method B using a 1:1 mixture of $\mathrm{MeOH}$ ( $2 \mathrm{~mL}$, to dissolve the amine) and aqueous 
phosphate buffer $(2 \mathrm{~mL})$ and a molar ratio monosaccharide: amine $3: 1$ at $65^{\circ} \mathrm{C}$ for $74 \mathrm{~h}$.

Method D. A stirred solution of the 5-amino-1,10phenanthroline (195 mg, $1 \mathrm{mmol})$, the monosaccharide ( $3 \mathrm{mmol}$ ) and ca. $4 \mathrm{mg}$ of $\left(\mathrm{NH}_{4}\right)_{2} \mathrm{SO}_{4}$ in $16 \mathrm{~mL}$ of $\mathrm{MeOH}$ was heated at 65 ${ }^{\circ} \mathrm{C}$ for 24 or $48 \mathrm{~h}$. During this time a pale yellow precipitate was accumulated. The reaction mixture was cooled and the solid obtained was separated by filtration and washed with $\mathrm{MeOH}$ (2x10 mL) and $\mathrm{H}_{2} \mathrm{O}(2 \times 10 \mathrm{~mL})$ to eliminate excess of sugar and possible traces of the starting amine and/or other by-products as well to remove the $\left(\mathrm{NH}_{4}\right)_{2} \mathrm{SO}_{4}$ salt, followed by $\mathrm{Et}_{2} \mathrm{O}$. This protocol provided pure $N$-(1,10-phenanthrolin-5-yl)- $\beta$ glycopyranosyl amines $2 \mathrm{a}, 2 \mathrm{c}$ and $2 \mathrm{~d}$. For derivatives $2 \mathrm{~b}$ and $2 \mathrm{e}$ the starting sugar could not be completely removed and a subsequent purification was required. The product was preadsorbed on silica gel and purified by flash chromatography. After drying in vacuum the purity of the products was checked by TLC, ${ }^{1} \mathrm{H}-\mathrm{NMR}$ and analytical data. Derivatives $2 \mathrm{a}-\mathrm{e}$ were obtained as monohydrates and exhibited poor solubility in water and organic solvents.

$N$-(1,10-phenanthrolin-5-yl)- $\boldsymbol{\beta}$ - $\boldsymbol{D}$-glucopyranosylamine (2a). Pale yellow powder; yield: $332 \mathrm{mg}(88 \%) ; R_{\mathrm{f}}=0.51 ; \mathrm{mp} 214-216$ ${ }^{\circ} \mathrm{C}$ (decomposition); [Found: $\mathrm{C}, 57.2 ; \mathrm{H}, 5.6 ; \mathrm{N}, 11.4$. $\mathrm{C}_{18} \mathrm{H}_{19} \mathrm{~N}_{3} \mathrm{O}_{5} \cdot \mathrm{H}_{2} \mathrm{O}$ requires $\left.\mathrm{C}, 57.6 ; \mathrm{H}, 5.6 ; \mathrm{N}, 11.2 \%\right] ;[\alpha]_{D}{ }^{22}-130$ (c 3.03 in DMSO); IR (KBr) $v_{\max } 3355$ br (NH and $\left.\mathrm{OH}\right), 1621 \mathrm{~s}$ $(\delta \mathrm{NH}), 1548 \mathrm{~s}(\mathrm{C}=\mathrm{C}), 1077 \mathrm{~s}, 1028 \mathrm{~s}, 737 \mathrm{~cm}^{-1} ; \delta_{\mathrm{H}}(500 \mathrm{MHz}$ $\left.\left(\mathrm{CD}_{3}\right)_{2} \mathrm{SO}\right) 3.21(1 \mathrm{H}$, tdap, $J$ 9.6, 8.7, $5.1 \mathrm{~Hz}, \mathrm{H}-4), 3.34(1 \mathrm{H}$, tdap, $J$ 8.7, 8.1, 4.4 Hz, H-3), $3.39(1 \mathrm{H}$, ddd, $J$ 9.6, 5.6, $2.2 \mathrm{~Hz}$, $\mathrm{H}-5), 3.49$ (2H, m, H-2, H-6a), 3.73(1H, ddd, $J-11.8,5.7,2.2$ $\mathrm{Hz}, \mathrm{H}-6 \mathrm{~b}), 4.48(1 \mathrm{H}$, tap, J $5.7 \mathrm{~Hz}, 6-\mathrm{OH}), 4.64(1 \mathrm{H}$, tap, $J$ 8.4, $7.7 \mathrm{~Hz}, \mathrm{H}-1), 4.97(1 \mathrm{H}, \mathrm{d}, J 5.1 \mathrm{~Hz}, 4-\mathrm{OH}), 5.05(2 \mathrm{H}$, dap, $J 4.4$ $\mathrm{Hz}, 2-\mathrm{OH}, 3-\mathrm{OH}), 6.89(1 \mathrm{H}, \mathrm{d}, J 7.7 \mathrm{~Hz}, \mathrm{NH}), 7.00\left(1 \mathrm{H}, \mathrm{s}, \mathrm{H}-6^{\prime}\right)$, $7.55\left(1 \mathrm{H}, \mathrm{dd}, J 8.1,4.3 \mathrm{~Hz}, \mathrm{H}-8^{\prime}\right), 7.75(1 \mathrm{H}, \mathrm{dd}, J 8.4,4.3 \mathrm{~Hz}, \mathrm{H}-$ $\left.3^{\prime}\right), 8.12\left(1 \mathrm{H}, \mathrm{dd}, J 8.1,1.6 \mathrm{~Hz}, \mathrm{H}-7^{\prime}\right), 8.74(1 \mathrm{H}, \mathrm{dd}, J 4.3,1.6$ Hz, H-9'), 8.84 (1H, dd, $J$ 8.4, $\left.1.6 \mathrm{~Hz}, \mathrm{H}^{-} 4^{\prime}\right), 9.05$ (1H, dd, $J 4.3$, $\left.1.6 \mathrm{~Hz}, \mathrm{H}-2^{\prime}\right) ; \delta_{\mathrm{C}}\left(125 \mathrm{MHz} ;\left(\mathrm{CD}_{3}\right)_{2} \mathrm{SO}\right) 60.4(\mathrm{C}-6), 69.7(\mathrm{C}-4)$, $72.1(\mathrm{C}-2), 77.1,77.2(\mathrm{C}-3, \mathrm{C}-5), 84.7\left(\mathrm{C}-1,{ }^{1} J_{\mathrm{C} 1-\mathrm{H} 1}=151 \mathrm{~Hz}\right)$, 101.3 (C-6'), 121.5, 121.6 (C-3', C-4'a), 122.8 (C-8'), 129.6, 130.1 (C-4', C-6'a), 133.3 (C-7'), 139.90, 140.5 (C-5', C-10'a), 145.2, 145.4 (C-9', C-10’b), 148.9 (C-2'); LRMS (ESI) m/z 358 $(\mathrm{M}+\mathrm{H})^{+}$.

$N$-(1,10-phenanthrolin-5-yl)- $\beta$ - $D$-galactopyranosylamine (2b). Pale yellow powder; yield: $254 \mathrm{mg}(68 \%) ; \mathrm{R}_{\mathrm{f}}=0.45 ; \mathrm{mp} 225-$ $228{ }^{\circ} \mathrm{C}$ (decomposition); [Found: C, 57.3; H, 5.3; N, 11.5. $\mathrm{C}_{18} \mathrm{H}_{19} \mathrm{~N}_{3} \mathrm{O}_{5} \cdot \mathrm{H}_{2} \mathrm{O}$ requires $\left.\mathrm{C}, 57.6 ; \mathrm{H}, 5.6 ; \mathrm{N}, 11.2 \%\right] ;[\alpha]_{D}{ }^{22}-95$ (c 2.54 in DMSO); IR (KBr) $v_{\max } 3402$ br (NH and $\left.\mathrm{OH}\right), 1616 \mathrm{~s}$ $(\delta \mathrm{NH}), 1538 \mathrm{~s}(\mathrm{C}=\mathrm{C}), 1075 \mathrm{~s}, 1042 \mathrm{~s}, 737 \mathrm{~cm}^{-1} ; \delta_{\mathrm{H}}(500 \mathrm{MHz}$; $\left.\left(\mathrm{CD}_{3}\right)_{2} \mathrm{SO}\right) 3.48(1 \mathrm{H}$, ddd, $J$ 9.3, 5.0, $3.3 \mathrm{~Hz}, \mathrm{H}-3), 3.52(1 \mathrm{H}$, ddd, $J-11.3,5.5,4.0 \mathrm{~Hz}, \mathrm{H}-6 \mathrm{a}), 3.57$ (1H, ddd, $J-11.3,6.1,4.5 \mathrm{~Hz}, \mathrm{H}-$ 6b), $3.66(1 \mathrm{H}, \mathrm{tap}, J 6.1,5.5 \mathrm{~Hz}, \mathrm{H}-5), 3.80(1 \mathrm{H}, \mathrm{dd}, J 3.9,3.3$ $\mathrm{Hz}, \mathrm{H}-4), 3.82(1 \mathrm{H}, \mathrm{ddd}, J 9.3,8.5,5.0 \mathrm{~Hz}, \mathrm{H}-2), 4.46(1 \mathrm{H}, \mathrm{d}, J$ $3.9 \mathrm{~Hz}, 4-\mathrm{OH}), 4.61(1 \mathrm{H}, \mathrm{tap}, J 4.5,4.0 \mathrm{~Hz}, 6-\mathrm{OH}), 4.62(1 \mathrm{H}$, tap, $J$ 8.5, $7.6 \mathrm{~Hz}, \mathrm{H}-1), 4.86(1 \mathrm{H}, \mathrm{d}, J 5.0 \mathrm{~Hz}, 3-\mathrm{OH}), 4.92(1 \mathrm{H}, \mathrm{d}, J$ $5.0 \mathrm{~Hz}, 2-\mathrm{OH}), 6.90(1 \mathrm{H}, \mathrm{d}, J 7.6 \mathrm{~Hz}, \mathrm{NH}), 7.01(1 \mathrm{H}, \mathrm{s}, \mathrm{H}-6$ '), $7.56\left(1 \mathrm{H}, \mathrm{dd}, J 8.1,4.2 \mathrm{~Hz}, \mathrm{H}-8^{\prime}\right), 7.75(1 \mathrm{H}, \mathrm{dd}, J 8.5,4.2 \mathrm{~Hz}, \mathrm{H}-$ 3'), $8.11(1 \mathrm{H}, \mathrm{dd}, J 8.1,1.7 \mathrm{~Hz}, \mathrm{H}-7$ '), $8.75(1 \mathrm{H}, \mathrm{dd}, J 4.2,1.7$ $\mathrm{Hz}, \mathrm{H}-9$ '), 8.87 (1H, dd, J 8.5, $1.6 \mathrm{~Hz}, \mathrm{H}-4$ '), $9.06(1 \mathrm{H}, \mathrm{dd}, J 4.2$, $\left.1.6 \mathrm{~Hz}, \mathrm{H}-2{ }^{\prime}\right) ; \delta_{\mathrm{C}}\left(125 \mathrm{MHz} ;\left(\mathrm{CD}_{3}\right)_{2} \mathrm{SO}\right) 60.1(\mathrm{C}-6), 67.9(\mathrm{C}-4)$, $69.2(\mathrm{C}-2), 73.7(\mathrm{C}-3), 75.4(\mathrm{C}-5), 85.2\left(\mathrm{C}-1,{ }^{1} J_{\mathrm{C} 1-\mathrm{H} 1} 151 \mathrm{~Hz}\right)$, 101.2 (C-6'), 121.5 (C-3', C-4'a), 122.8 (C-8'), 129.6, 130.2 (C4', C-6'a), 133.2 (C-7'), 139.9, 140.5 (C-5', C-10'a), 145.2, 145.4 (C-9', C-10'b), 148.8 (C-2'); LRMS (ESI) $m / z 358$ (M + $\mathrm{H})^{+}$.
$\boldsymbol{N}$-(1,10-phenanthrolin-5-yl)- $\boldsymbol{\beta}$ - $\boldsymbol{D}$-mannopyranosylamine

(2c). Slightly yellowish solid; yield: $336 \mathrm{mg}(90 \%) ; R_{\mathrm{f}}=0.42$; mp 239-242 ${ }^{\circ} \mathrm{C}$ (decomposition); [Found: $\mathrm{C}, 57.7 ; \mathrm{H}, 5.5 ; \mathrm{N}$, 11.4. $\mathrm{C}_{18} \mathrm{H}_{19} \mathrm{~N}_{3} \mathrm{O}_{5} \cdot \mathrm{H}_{2} \mathrm{O}$ requires $\left.\mathrm{C}, 57.6 ; \mathrm{H}, 5.6 ; \mathrm{N}, 11.2 \%\right] ;[\alpha]_{\mathrm{D}}{ }^{22}$ -149 (c 1.70 in DMSO); IR (KBr) $v_{\max } 3307$ br (NH and $\left.\mathrm{OH}\right)$, $1617 \mathrm{~s}(\delta \mathrm{NH}), 1520 \mathrm{~s}(\mathrm{C}=\mathrm{C}), 1086 \mathrm{~s}, 1058 \mathrm{~s}, 741 \mathrm{~cm}^{-1} ; \delta_{\mathrm{H}}(500$ $\left.\mathrm{MHz} ;\left(\mathrm{CD}_{3}\right)_{2} \mathrm{SO}\right) 3.34(1 \mathrm{H}, \mathrm{ddd}, J 9.4,5.9,2.1 \mathrm{~Hz}, \mathrm{H}-5), 3.45$ (1H, ddd, J 9.4, 9.1, 4.9 Hz, H-4), 3.47 (1H, ddd, $J-11.7,6.3$, $5.9 \mathrm{~Hz}, \mathrm{H}-6 \mathrm{a}), 3.50(1 \mathrm{H}$, ddd, $J 9.1,6.1,3.2 \mathrm{~Hz}, \mathrm{H}-3), 3.73(1 \mathrm{H}$, ddd, $J-11.7,5.4,2.1 \mathrm{~Hz}, \mathrm{H}-6 \mathrm{~b}), 3.93(1 \mathrm{H}, \mathrm{dd}, J 4.9,3.2 \mathrm{~Hz}, \mathrm{H}-2)$, $4.40(1 \mathrm{H}, \mathrm{dd}, J 6.3,5.4 \mathrm{~Hz}, 6-\mathrm{OH}), 4.74(1 \mathrm{H}, \mathrm{d}, J 6.1 \mathrm{~Hz}, 3-\mathrm{OH})$, $4.80(1 \mathrm{H}, \mathrm{d}, J 4.9 \mathrm{~Hz}, 4-\mathrm{OH}), 5.01(1 \mathrm{H}, \mathrm{d}, J 9.0 \mathrm{~Hz}, \mathrm{H}-1), 5.20$ $(1 \mathrm{H}, \mathrm{d}, J 4.9 \mathrm{~Hz}, 2-\mathrm{OH}), 6.27(1 \mathrm{H}, \mathrm{d}, J 9.0 \mathrm{~Hz}, \mathrm{NH}), 7.07(1 \mathrm{H}, \mathrm{s}$, H-6'), 7.58 (1H, dd, $J$ 8.1, $4.2 \mathrm{~Hz}, \mathrm{H}-8^{\prime}$ '), 7.78(1H, dd, J 8.6, 4.2 Hz, H-3'), 8.13 (1H, dd, $J$ 8.1, 1.6 Hz, H-7'), 8.60 (1H, dd, $J 8.8$, $1.6 \mathrm{~Hz}, \mathrm{H}-4^{\prime}$ ), 8.77 (1H, dd, $J 4.2,1.6 \mathrm{~Hz}, \mathrm{H}-9$ '), 9.08 (1H, dd, $J$ $4.2,1.6 \mathrm{~Hz}, \mathrm{H}-2$ '); $\delta_{\mathrm{C}}\left(125 \mathrm{MHz} ;\left(\mathrm{CD}_{3}\right)_{2} \mathrm{SO}\right) 60.7(\mathrm{C}-6), 66.7(\mathrm{C}-$ 4), 70.6 (C-2), 73.8 (C-3), $77.7(\mathrm{C}-5), 81.4\left(\mathrm{C}-1,{ }^{l} J_{\mathrm{C} 1-\mathrm{H} 1} 158 \mathrm{~Hz}\right)$, 102.5 (C-6'), 121.4 , 121.9(C-3', C-4'a), 122.8 (C-8'), 129.2, 129.5 (C-4', C-6'a), 133.4 (C-7'), 138.7, 140.7 (C-5', C-10'a), 145.4, 145.5 (C-9', C-10’b), 149.0 (C-2'); LRMS (ESI) m/z 358 $(\mathrm{M}+\mathrm{H})^{+}$

$N$-(1,10-phenanthrolin-5-yl)- $\beta$ - $L$-rhamnopyranosylamine (2d) Slightly yellowish solid; yield: $324 \mathrm{mg}(90 \%) ; R_{\mathrm{f}}=0.58 ; \mathrm{mp}$ 216-218 ${ }^{\circ} \mathrm{C}$ (decomposition); [Found: C, 60.5; H, 5.7; N, 11.4. $\mathrm{C}_{18} \mathrm{H}_{19} \mathrm{~N}_{3} \mathrm{O}_{4} \cdot \mathrm{H}_{2} \mathrm{O}$ requires $\left.\mathrm{C}, 60.2 ; \mathrm{H}, 5.9 ; \mathrm{N}, 11.7 \%\right] ;[\alpha]_{\mathrm{D}}{ }^{22}+119$ (c 2.80 in DMSO); IR (KBr) $v_{\max } 3308 \mathrm{br}(\mathrm{NH}$ and $\mathrm{OH}), 1617 \mathrm{~s}$ $(\delta \mathrm{NH}), 1519 \mathrm{~s}(\mathrm{C}=\mathrm{C}), 1091 \mathrm{~s}, 1066 \mathrm{~s}, 739 \mathrm{~cm}^{-1} ; \delta_{\mathrm{H}}(500 \mathrm{MHz}$; $\left.\left(\mathrm{CD}_{3}\right)_{2} \mathrm{SO}\right) 1.19\left(3 \mathrm{H}, \mathrm{d}, J 6.2 \mathrm{~Hz}, \mathrm{CH}_{3}-6\right), 3.23$ (1H, tdap, $J$ 9.3, $5.4 \mathrm{~Hz}, \mathrm{H}-4), 3.42$ (1H, dq, $J 9.3,6.2 \mathrm{~Hz}, \mathrm{H}-5), 3.46$ (1H, ddd, $J$ 9.3, 6.0, $3.4 \mathrm{~Hz}, \mathrm{H}-3), 3.92$ (1H, dd, J 5.0, $3.4 \mathrm{~Hz}, \mathrm{H}-2), 4.73$ $(1 \mathrm{H}, \mathrm{d}, J 6.0 \mathrm{~Hz}, 3-\mathrm{OH}), 4.84(1 \mathrm{H}, \mathrm{d}, J 5.4 \mathrm{~Hz}, 4-\mathrm{OH}), 5.02(1 \mathrm{H}$, $\mathrm{d}, J 9.0 \mathrm{~Hz}, \mathrm{H}-1), 5.23(1 \mathrm{H}, \mathrm{d}, J 5.0 \mathrm{~Hz}, 2-\mathrm{OH}), 6.24(1 \mathrm{H}, \mathrm{d}, J 9.0$ $\mathrm{Hz}, \mathrm{NH}), 7.03$ (1H, s, H-6'), 7.57 (1H, dd, J 8.1, 4.2 Hz, H-8'), $7.78\left(1 \mathrm{H}, \mathrm{dd}, J 8.4,4.2 \mathrm{~Hz}, \mathrm{H}-3^{\prime}\right), 8.20(1 \mathrm{H}, \mathrm{dd}, J 8.1,1.8 \mathrm{~Hz}, \mathrm{H}-$ $\left.7^{\prime}\right), 8.59\left(1 \mathrm{H}, \mathrm{dd}, J 8.4,1.6 \mathrm{~Hz}, \mathrm{H}-4^{\prime}\right), 8.77(1 \mathrm{H}, \mathrm{dd}, J 4.2,1.8$ $\left.\mathrm{Hz}, \mathrm{H}-9^{\prime}\right), 9.08$ (1H, dd, $J$ 4.2, $\left.1.6 \mathrm{~Hz}, \mathrm{H}-2^{\prime}\right) ; \delta_{\mathrm{C}}(125 \mathrm{MHz}$; $\left.\left(\mathrm{CD}_{3}\right)_{2} \mathrm{SO}\right) 17.6$ (C-6), 70.7, 71.6 (C-2, C-4), 72.3, 73.5 (C-3, C5), $81.0\left(\mathrm{C}-1,{ }^{1} J_{\mathrm{C} 1-\mathrm{H} 1} 157 \mathrm{~Hz}\right), 102.0$ (C-6'), 121.3, $121.9(\mathrm{C}-3$ ', C4'a), 122.8 (C-8'), 129.2, 129.4 (C-4', C-6'a), 133.4 (C-7'), 138.6, 140.7 (C-5', C-10'a), 145.4, 145.6 (C-9', C-10’b), 149.0 (C-2'); LRMS (ESI) $m / z, 342(\mathrm{M}+\mathrm{H})^{+}$.

$\boldsymbol{N}$-(1,10-phenanthrolin-5-yl)- $\boldsymbol{\beta}$-L-fucopyranosylamine (2e). Pale yellow powder; yield: $239 \mathrm{mg}(67 \%) ; R_{\mathrm{f}}=0.55 ; \mathrm{mp} 230-232$ ${ }^{\circ} \mathrm{C}$ (decomposition); [Found: $\mathrm{C}, 60.4 ; \mathrm{H}, 6.2 ; \mathrm{N}, 12.0$. $\mathrm{C}_{18} \mathrm{H}_{19} \mathrm{~N}_{3} \mathrm{O}_{4} \cdot \mathrm{H}_{2} \mathrm{O}$ requires $\left.\mathrm{C}, 60.2 ; \mathrm{H}, 5.9 ; \mathrm{N}, 11.7 \%\right] ;[\alpha]_{D}{ }^{22}+82$ (c 2.01 in DMSO); IR (KBr) $v_{\max } 3384 \mathrm{br}(\mathrm{NH}$ and $\mathrm{OH}), 1618 \mathrm{~s}$ $(\delta \mathrm{NH}), 1542 \mathrm{~s}(\mathrm{C}=\mathrm{C}), 1081 \mathrm{~s}, 1069 \mathrm{~s}, 735 \mathrm{~cm}^{-1} ; \delta_{\mathrm{H}}(500 \mathrm{MHz}$; $\left.\left(\mathrm{CD}_{3}\right)_{2} \mathrm{SO}\right) 1.18\left(3 \mathrm{H}, \mathrm{d}, J\right.$ 6.3, $\left.\mathrm{CH}_{3}-6\right), 3.49(1 \mathrm{H}, \mathrm{ddd}, J$ 9.4, 5.4, 3.3, H-3), 3.57 (1H, tap, $J$ 4.3, 3.3, H-4), 3.79 (1H, ddd, $J 9.4$, 8.5, 5.1, H-2), $3846(1 \mathrm{H}, \mathrm{q}, J 6.3, \mathrm{H}-5), 3.80(1 \mathrm{H}, \mathrm{dd}, J 3.9,3.3 \mathrm{~m}$, $\mathrm{H}-4), 3.82$ (1H, ddd, $J$ 9.3, 8.5, 5.0, H-2), 4.46 (1H, d, J 3.9, 4$\mathrm{OH}), 4.50(1 \mathrm{H}, \mathrm{d}, J 4.3,4-\mathrm{OH}), 4.62(1 \mathrm{H}, \mathrm{tap}, J 8.5,7.9, \mathrm{H}-1)$, $4.82(1 \mathrm{H}, \mathrm{d}, J 5.4,3-\mathrm{OH}), 4.86(1 \mathrm{H}, \mathrm{d}, J 5.1,2-\mathrm{OH}), 6.86(1 \mathrm{H}, \mathrm{d}$, $J$ 7.9, NH), $6.97(1 \mathrm{H}, \mathrm{s}, \mathrm{H}-6$ '), $7.56(1 \mathrm{H}, \mathrm{dd}, J$ 8.2, 4.2, H-8'), 7.76 (1H, dd, J 8.6, 4.2 Hz, H-3'), 8.17 (1H, dd, $J$ 8.2, 1.7, H-7'), 8.75 (1H, dd, $J$ 4.2, 1.7, H-9'), 8.86 (1H, dd, J 8.6, 1.6, H-4'), $9.07\left(1 \mathrm{H}, \mathrm{dd}, J 4.2,1.6, \mathrm{H}-2\right.$ '); $\delta_{\mathrm{C}}\left(125 \mathrm{MHz}\right.$; $\left.\left(\mathrm{CD}_{3}\right)_{2} \mathrm{SO}\right) 16.5(\mathrm{C}-$ 6), 68.9 (C-2), 70.2 (C-5), 70.8 (C-4), 73.8 (C-3), 84.8 (C-1, ${ }^{1} J_{\mathrm{C} 1-}$ н1 $151 \mathrm{~Hz}$ ), 100.8 (C-6'), 121.5, 121.6 (C-3', C-4'a), 122.8 (C8'), 129.7, 130.3 (C-4', C-6'a), 133.3 (C-7'), 140.1, 140.5 (C-5', C-10'a), 145.2, 145.4 (C-9', C-10'b), 148.9 (C-2'); LRMS (ESI) $m / z, 342(\mathrm{M}+\mathrm{H})^{+}$. 


\section{Synthesis of copper(II) complexes.} better solubility properties. requires 839.1824 . $\left.-\mathrm{NO}_{3}\right)^{+}\left[\mathrm{Cu}(\mathrm{Phe}-\mathrm{NH}-\mathrm{Gly})_{2} \mathrm{NO}_{3}\right]^{+}$. $\left.-\mathrm{NO}_{3}\right)^{+}\left[\mathrm{Cu}(\mathrm{Phe}-\mathrm{NH}-\mathrm{Gly})_{2} \mathrm{NO}_{3}\right]^{+}$. $\left.-\mathrm{NO}_{3}\right)^{+}\left[\mathrm{Cu}(\text { Phe-NH-Gly })_{2} \mathrm{NO}_{3}\right]^{+}$.

\section{Acknowledgments}

General method. A stirred suspension of the $N$-phenanthroline glycopyranosylamine 2a-e $(0.1 \mathrm{mmol})$ in DMSO $(1 \mathrm{~mL})$ was heated at $65^{\circ} \mathrm{C}$ for $30 \mathrm{~min}$ (a clear solution was obtained for $\mathbf{2 a}$, 2b and 2e) and then an ethanol solution of $\mathrm{Cu}\left(\mathrm{NO}_{3}\right)_{2} \cdot 3 \mathrm{H}_{2} \mathrm{O}$ (0.052 M, $0.052 \mathrm{mmol})$ was added. The colour changed immediately to dark green and after heating for $6 \mathrm{~h}$ at this temperature the solution obtained was allowed to stand overnight at room temperature. Solvents were removed and the residue dissolved in the minimum amount of $\mathrm{MeOH}$ and treated with acetonitrile. The precipitate was separated out, washed with acetonitrile and dried in vacuum, affording the pure $\mathrm{Cu}$ (II) complexes 3a-e as green powders. Single crystals suitable for Xray analysis could not be obtained in the different conditions assayed. While the $N$-phenanthroline glycopyranosylamines 2a-e have disappointing solubility, their $\mathrm{Cu}$ complexes exhibited

$\mathrm{Cu}(\mathrm{Phe}-\mathrm{NH}-\mathrm{Glucopyranosylamine})_{2}\left(\mathrm{NO}_{3}\right)_{2} \cdot \mathbf{4 H}_{2} \mathrm{O}$ (3a). Green powder; yield: $41 \mathrm{mg}$ (84\%); [Found: $\mathrm{C}, 43.9 ; \mathrm{H}, 4.6$; N, 11.4. $\mathrm{C}_{36} \mathrm{H}_{38} \mathrm{CuN}_{8} \mathrm{O}_{16} \cdot 4 \mathrm{H}_{2} \mathrm{O}$ requires $\mathrm{C}, 44.4 ; \mathrm{H}, 4.8 ; \mathrm{N}, 11.5 \%$ ]; IR $(\mathrm{KBr}) v_{\max } 3355$ br $(\mathrm{NH}$ and $\mathrm{OH}), 1625(\delta \mathrm{NH}), 1600,1542$ $(\mathrm{C}=\mathrm{C}), 1384 \mathrm{~s}\left(\mathrm{NO}_{3}{ }^{-}\right), 1074,1015,724 \mathrm{~cm}^{-1}$; FAB-MS (m-NBA) $\mathrm{m} / z, 839\left(\mathrm{M}-\mathrm{NO}_{3}\right)^{+}$; LRMS (ESI, $\left.\mathrm{H}_{2} \mathrm{O}-\mathrm{CH}_{3} \mathrm{COOH}\right) \mathrm{m} / \mathrm{z} 839$ (2) $\left(\mathrm{M}-\mathrm{NO}_{3}\right)^{+}\left[\mathrm{Cu}(\mathrm{Phe}-\mathrm{NH}-\mathrm{Gly})_{2} \mathrm{NO}_{3}\right]^{+}, 836$ (10) $[\mathrm{Cu}(\mathrm{Phe}-\mathrm{NH}-$ Gly) $\left.{ }_{2} \mathrm{CH}_{3} \mathrm{COO}\right]^{+}, 482$ (35) $\left.\mathrm{Cu}(\mathrm{Phe}-\mathrm{NH}-\mathrm{Gly}) \mathrm{NO}_{3}\right]^{+}, 479$ (68) $\left[\mathrm{Cu}(\mathrm{Phe}-\mathrm{NH}-\mathrm{Gly}) \mathrm{CH}_{3} \mathrm{COO}\right]^{+}, 388.5$ (47) $\left[\mathrm{Cu}(\mathrm{Phe}-\mathrm{NH}-\mathrm{Gly})_{2}\right]^{+2}$, $358(100 \%)$ [(Phe-NH-Gly) $+\mathrm{H}^{+}$; HRMS (ESI-TOF, $\left.\mathrm{H}_{2} \mathrm{O}\right):(\mathrm{M}-$ $\left.\mathrm{NO}_{3}\right)^{+}\left[\mathrm{Cu}(\mathrm{Phe}-\mathrm{NH}-\mathrm{Gly})_{2} \mathrm{NO}_{3}\right]^{+}$, found $839.1820 \mathrm{C}_{36} \mathrm{H}_{38} \mathrm{CuN}_{7} \mathrm{O}_{13}$

$\mathrm{Cu}(\text { Phe-NH-Galactopyranosylamine })_{2}\left(\mathrm{NO}_{3}\right)_{2} \cdot \mathbf{4} \mathbf{H}_{2} \mathrm{O}$ (3b). Dark green powder; yield: $39 \mathrm{mg}(80 \%)$; [Found: $\mathrm{C}, 44.0 ; \mathrm{H}, 4.7 ; \mathrm{N}$, 11.7. $\mathrm{C}_{36} \mathrm{H}_{38} \mathrm{CuN}_{8} \mathrm{O}_{16} \cdot 4 \mathrm{H}_{2} \mathrm{O}$ requires $\left.\mathrm{C}, 44.4 ; \mathrm{H}, 4.8 ; \mathrm{N}, 11.5 \%\right]$; $\mathrm{IR}(\mathrm{KBr}) v_{\max } 3365 \mathrm{br}(\mathrm{NH}$ and $\mathrm{OH}), 1623(\delta \mathrm{NH}), 1535(\mathrm{C}=\mathrm{C})$,

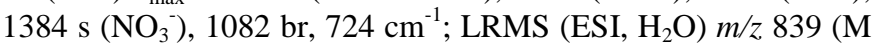

$\mathrm{Cu}(\text { Phe-NH-Mannopyranosylamine })_{2}\left(\mathrm{NO}_{3}\right)_{2} \cdot \mathbf{4} \mathrm{H}_{2} \mathrm{O}(3 \mathrm{c})$. Green powder; yield: $46 \mathrm{mg}(86 \%)$; [Found: $\mathrm{C}, 44.1 ; \mathrm{H}, 4.5 ; \mathrm{N}, 11.9$. $\mathrm{C}_{36} \mathrm{H}_{38} \mathrm{CuN}_{8} \mathrm{O}_{16} \cdot 4 \mathrm{H}_{2} \mathrm{O}$ requires $\mathrm{C}, 44.4 ; \mathrm{H}, 4.8 ; \mathrm{N}, 11.5 \%$ ]; IR $(\mathrm{KBr}) v_{\max } 3351$ br $(\mathrm{NH}$ and $\mathrm{OH}), 1624(\delta \mathrm{NH}), 1528(\mathrm{C}=\mathrm{C})$, $1384 \mathrm{~s}\left(\mathrm{NO}_{3}^{-}\right), 1104 \mathrm{br}, 721 \mathrm{~cm}^{-1}$; LRMS (ESI, H2O) $\mathrm{m} / \mathrm{z} 839(\mathrm{M}$

$\left.\mathrm{Cu}(\text { Phe-NH-Rhamnopyranosylamine })_{2} \mathrm{NO}_{3}\right)_{2} \cdot \mathbf{4} \mathrm{H}_{2} \mathrm{O}$ (3d). Green powder; yield: $30 \mathrm{mg}$ (64\%); [Found: C, 45.5; H, 4.5; N, 12.3. $\mathrm{C}_{36} \mathrm{H}_{38} \mathrm{CuN}_{8} \mathrm{O}_{14} \cdot 4 \mathrm{H}_{2} \mathrm{O}$ requires $\left.\mathrm{C}, 45.9 ; \mathrm{H}, 4.9 ; \mathrm{N}, 11.9 \%\right]$; IR $(\mathrm{KBr}) v_{\max } 3380 \mathrm{br}(\mathrm{NH}$ and $\mathrm{OH}), 1623(\delta \mathrm{NH}), 1528(\mathrm{C}=\mathrm{C})$, $1384 \mathrm{~s}\left(\mathrm{NO}_{3}^{-}\right), 1107 \mathrm{br}, 1056 \mathrm{br}, 721 \mathrm{~cm}^{-1}$; LRMS (ESI, $\left.\mathrm{H}_{2} \mathrm{O}\right) \mathrm{m} / \mathrm{z}$ $807\left(\mathrm{M}-\mathrm{NO}_{3}\right)^{+}\left[\mathrm{Cu}(\mathrm{Phe}-\mathrm{NH}-\mathrm{Gly})_{2} \mathrm{NO}_{3}\right]^{+}$.

$\mathrm{Cu}(\text { Phe-NH-Fucopyranosylamine })_{2}\left(\mathbf{N O}_{3}\right)_{2} \cdot \mathbf{4 H}_{\mathbf{2}} \mathrm{O} \quad(3 \mathrm{e})$. Green powder; yield: $33 \mathrm{mg}$ (70\%); [Found: $\mathrm{C}, 45.4 ; \mathrm{H}, 4.6$; N, 11.6. $\mathrm{C}_{36} \mathrm{H}_{38} \mathrm{CuN}_{8} \mathrm{O}_{14} \cdot 4 \mathrm{H}_{2} \mathrm{O}$ requires $\mathrm{C}, 45.9 ; \mathrm{H}, 4.9 ; \mathrm{N}, 11.9 \%$ ]; IR $(\mathrm{KBr}) v_{\max } 3406$ br $(\mathrm{NH}$ and $\mathrm{OH}), 1623(\delta \mathrm{NH}), 1536(\mathrm{C}=\mathrm{C})$,

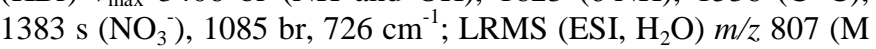

This research has received funding from the MICINN (project CTQ2011-26822), the MINECO (project CTQ2012-32711) and the European Community's Seventh Framework Programme ([FP7/2007-2013, under grant agreement 248638, to L.G. and K.D.]). We thank C. García for her collaboration in the synthesis of the $\mathrm{Cu}(\mathrm{II})$ complexes.

\section{Supplementary Material}

${ }^{1} \mathrm{H}$ and ${ }^{13} \mathrm{C}$ NMR spectra of $N$-(1,10-phenanthrolin-5-yl)- $\beta$ glycopyranosylamines 2a-e, 2D-NMR spectra of $\mathbf{2 a}$ and MS spectra of $\mathrm{Cu}(\mathrm{II})$ complex 3a. Supplementary data associated with this article can be found at...

\section{References and notes}

1. Norris, P. Curr. Top. Med. Chem. 2008, 8, 101-113.

2. Prudhomme, M. Curr. Med. Chem.: Anti-Cancer Agents 2004, 4, 509-521.

3. Garbutcheon-Singh, K. B.; Grant, M. P.; Harper, B. W.; KrauseHeuer, A. M.; Manohar, M.; Orkey, N.; Aldrich-Wright, J. R. Curr. Top. Med. Chem. 2011, 11, 521-542.

4. (a) Wesselina, D.; Neykov, M.; Kaloyanov, N.; Toshkova, R.; Dimitrov, G. Eur. J. Med. Chem. 2009, 44, 2720-2723; (b) Ramakrishnan, S.; Rajendiran, V.; Palaniandavar, M.; Periasamy, V. S.; Srinag, B. S.; Krishnamurthy, H.; Akbarsha, M. A. Inorg. Chem. 2009, 48, 1309-1322; (c) Arias, M. S.; González-Álvarez, M.; Fernández, M. J.; Lorente, A.; Alzuet, G.; Borrás, J. J. Inorg. Biochem. 2009, 103, 1069-1073; (d) González-Álvarez, M.; Arias, M. S.; Fernández, M. J.; Gude, L.; Lorente, A.; Alzuet, G.; Borrás, J. Bioorg. Med. Chem. Lett. 2008, 18, 3286-3290; (e) Thomas, A. M.; Nethaji, M.; Chakravarty, A. R. J. Inorg. Biochem. 2004, 98, 1087-1094; (f) Chikira, M.; Tomizava, Y.; Fukita, D.; Sugizaki, T.; Sugawara, N.; Yamazaki, T.; Sasano, A.; Shindo, S.; Palaniandavar, M.; Anthroline, W. E. J. Inorg. Biochem. 2002, 89, $163-173$.

5. Mocellin, S.; Pooley, K. A.; Nitti, D. Trends Mol. Med. 2013, 19, 125-133

6. Armanios, M. J. Clin. Invest. 2013, 123, 996-1002.

7. Kim, N. W.; Piatyszek, M. A.; Prowse, K. R.; Harley, C. B.; West, M. D.; Ho, P. L.; Coviello, G.M.; Wright, W.E.; Weinrich, S. L.; Shay, J. W. Science, 1994, 266, 2011-2015.

8. (a) Ruden, M.; Puri, N. Cancer Treat. Rev. 2013, 39,444-456; (b) Harley, C. B. Nat. Rev. Cancer, 2008, 8, 167-179.

9. Balasubramanian, S.; Hurley, L. H.; Neidle, S. Nat. Rev. Drug Discov. 2011, 10, 261-275.

10. (a) Murat, P.; Singh, Y.; Defrancq E. Chem. Soc. Rev. 2011, 40, 5293-5307. (b) Yang, D.; Okamoto, K. Future Med. Chem., 2010, 2, 619-646;

11. (a) Campbell, N. H.; Abd Karim, N. H.; Parkinson, G. N.; Gunaratnam, M.; Petrucci, V.; Todd, A. K.; Vilar, R.; Neidle, S. J. Med. Chem, 2012, 55, 209-222; (b) Castor, K. J.; Mancini, J.; Fakhoury, J.; Weill, N.; Kieltyka, R.; Englebienne, P.; Avakyan, N.; Mittermaier, A.; Autexier, Ch.; Moitessier, N.; Sleiman, H. ChemMedChem, 2012, 7, 85-94.

12. (a) Dixon, I. M.; López, F.; Tejera, A. M.; Estève, J.-P.; Blasco, M. A.; Pratviel, G.; Meunier, B. J. Am. Chem. Soc. 2007, 129, 1502-1503; (b) Tan, J.-H.; Gu L.-Q.; Wu, J.-Y. Mini Rev. Med. Chem. 2008, 8, 1163-1178.

13. (a) Wei, C.; Wang, Y.; Zhang, M. Org. Biomol. Chem. 2013, 11, 2355-2364; (b) Larsen, A. F.; Nielsen, M. C.; Ulven, T. Chem. Eur. J. 2012, 18, 10892-10902; (c) Wang, L. H.; Wen,Y.; Liu, J.; Zhou, J.; Li, C.; Wei, C. Y. Org. Biomol. Chem. 2011, 9, 26482653; (d) Bianco, S.; Musetti, C.; Waldeck, A.; Sparapani, S.; Seitz, J. D.; Krapcho, A. P.; Palumbo, M.; Sissi, C. Dalton Trans. 2010, 39, 5833-5841; (e) Reed, J. E.; White, A. J. P.; Neidle, S.; Vilar, R. Dalton Trans. 2009, 2558-2568; Nielsen, M. C.; Borch, J.; Ulven, T. Bioorg. Med. Chem. 2009, 17, 8241-8246; (f) Kieltyka, R.; Fakhoury, J.; Moitessier, N.; Sleiman, H. F. Chem. Eur. J. 2008, 14, 1145-1154; (g) De Cian, A.; DeLemos, E.; Mergny, J.-L.; Teulade-Fichou, M.-P.; Monchaud, D. J. Am. Chem. Soc. 2007, 129, 1856-1857.

14. Gómez-Pinto, I.; Vengut-Climent, E.; Lucas, R.; Aviñó, A.; Reitja, R.; González, C.; Morales. J. C. Chem. Eur. J. 2013, 19, 1920-1927 and references cited herein. 
15. Bugaut, A.; Jantos, K.; Wietor, J.-L.; Rodriguez, R.; Sanders, J. K. M.; Balasubramanian, S. Angew. Chem. Int. Ed., 2008, 47, 26772680.

16. (a) Fusaro, M. B.; Chagnault, V.; Postel, D. Tetrahedron, 2013, 69, 542-550; (b) Dhinakaran M. K.; Das, T. M. Org. Biomol. Chem. 2012, 10, 2077-2083; (c) Rajasekar, M.; Khan, S. M.; Devaraj, S. N.; Das, T. M. Carbohydr. Res. 2011, 346, 1776-1785; (d) Genady, A. R.; El-Zaria, M. E. Appl. Organometal. Chem. 2008, 227-232.

17. (a) Rajsekhar, G.; Rao, C. P.; Saarenketo, P.; Kolehmainen, E.; Rissanen, K. Carbohydr. Res. 2002, 337, 187-194; (b) Qian, X.; Li, Z.; Song, G. Carbohydr. Res. 2001, 336, 79-82

18. (a) Gokhale, M. Y.; Kirsch, L. E. J. Pharm. Sci. 2009, 98, 46394649; (b) Kublashvili, R. I.; Labartkava, M. O.; Giorgadze, K. P.; Ugrekhelidze, D. Sh. Chem. Nat. Compd. 2008, 44, 413-415.

19. Du, W.; Hu, Y. Synth. Commun. 2004, 34, 2987-2992

20. Chisholm, J. D.; van Vranken, D. L. J. Org. Chem. 2000, 65, 7541-7553.

21. Bridiau, N.; Cabane, S.; Maugard, T. Tetrahedron, 2009, 65, 531535 .

22. Bridiau, N.; Benmansour, M.; Legoy, M. D.; Maugard. T. Tetrahedron, 2007, 63, 4178-4183.

23. Das, T. M.; Rao, C. P.; Kolehmainen, E. Carbohydr. Res. 2001, $334,261-269$

24. Duus, J. O.; Gotfredsen, C. H.; Bock, K. Chem. Rev. 2000, 100, 4589-4614.

25. Batchelor, R. J.; Green, D. F.; Johnston, B. D.; Patrick, B. O.; Pinto, B. M. Carbohydr. Res. 2001, 330, 421-426.

26. (a) Zhong K.-L.; Cao, G.-Q. Acta Cryst. 2013, E69, m40-m41; (b) Catalan, K. J.; Jackson, S.; Zubkowski, J. D.; Perry, D. L.; Valente, E. J.; Feliu L. A.; Polanco, A. Polyhedron, 1995, 14, 2165-2171; (c) Murphy, G.; Murphy, C.; Murphy, B.; Brian, H. J. Chem. Soc., Dalton Trans. 1997, 2653-2660.

27. Lecomte, J. P.; Mesmaeker, A. K. D.; Demeunynck, M.; Lhomme, J. J. Chem. Soc. Faraday Trans. 1993, 89, 3261-3269. 